https://journal.uwgm.ac.id/index.php/abdimasmahakam

E-ISSN: 2549-5755

Januari 2020, Vol. 4 No. 01

Received: September 2019

Accepted: Desember2019

Published: Januari 2020

Article DOI: http://dx.doi.org/ 10.24903/jam.v4i1.548

\title{
Pengembangan Keprofesian Berkelanjutan bagi Guru-Guru di SLB Negeri Martapura
}

\author{
Muh. Fajaruddin Atsnan \\ STKIP PGRI Banjarmasin \\ fajaratsnan@gmail.com \\ Rahmita Yuliana Gazali \\ STKIP PGRI Banjarmasin \\ rahmitayulianagazali@yahoo.com \\ Fujianor Maulana \\ STKIP PGRI Banjarmasin \\ fujianormaulana@gmail.com \\ Syarief Fajaruddin \\ Universitas Negeri Yogyakarta \\ syarieff@uny.ac.id
}

\begin{abstract}
Abstrak
Mayoritas guru di SLB Negeri Martapura, Kalimantan Selatan, mengalami kesulitan dalam melakukan penelitian, menulis di jurnal pendidikan, serta menulis buku-buku untuk anak SLB di penerbit dan artikel ilmiah populer di media massa. Padahal, banyak masalah baik itu tentang pembelajaran maupun anak di SLB, yang bisa diangkat sebagai judul penelitian maupun artikel. Salah satu solusi untuk menjawab masalah guru-guru SLB Negeri Martapura adalah dengan Program Kemitraan Masyarakat Stimulus (PKMS) Pengembangan Keprofesian Berkelanjutan (PKB) Bagi Guru-guru di SLB Negeri Martapura Kabupaten Banjar. Pengembangan kompetensi guru yang dilaksanakan sesuai dengan kebutuhan, bertahap, berkelanjutan untuk meningkatkan profesionalitasnya. Tujuannya pengabdian ini adalah memberikan motivasi kepada guru-guru SLB Negeri Martapura untuk menyusun PKB dalam bentuk (1) sosialisasi selayang pandang tentang PKB (2) workshop penyusunan Penelitian Tindakan Kelas (PTK) (3) workshop menulis di jurnal pendidikan (4) workshop menulis buku-buku pendidikan dan artikel ilmiah populer di media massa. Hasil pengabdian menunjukkan bahwa guru-guru SLB Negeri Martapura lebih termotivasi untuk menyusun PKB, berupa menyusun PTK (proposal), menulis di jurnal, serta menulis buku-buku untuk anak SLB dan artikel ilmiah (opini) di media massa, meskipun baru sebatas draft.
\end{abstract}

Kata Kunci: PKB; PTK; jurnal; buku; artikel. 


\section{(A) ABDIMAS}

https://journal.uwgm.ac.id/index.php/abdimasmahakam

E-ISSN: 2549-5755

Januari 2020, Vol. 4 No. 01

\section{Pendahuluan}

Undang-Undang Nomor 14 Tahun 2005 Tentang Guru dan Dosen mengamanatkan bahwa guru sebagai tenaga profesional mempunyai fungsi, peran, dan kedudukan yang sangat penting dalam mencapai visi pendidikan yaitu menciptakan insan indonesia cerdas dan kompetitif. Apalagi di abad 21 ini, semua insan Indonesia, termasuk guru, seyogyanya memiliki 4C mencakup creativity and innovation, critical thinking and problem solving, collaboration, and communication. Pengembangan insan cendekia tidak cukup pada hand-on skills, tetapi membutuhkan Higher Order Skills "Four Cs" (HOS4C) yaitu Creativity, Critical Thinking, Communication, Collaboration (Chinien \& Sigh, 2009; Wagner, 2008; Lucas Spencer \& Claxton, 2012).

Bagi guru, salah satu cara untuk menjadi insan cerdas dan kompetitif bisa dicapai melalui kegiatan pengembangan keprofesian berkelanjutan (PKB). Menurut Permennegpan dan Reformasi Birokrasi Nomor 16 Tahun 2009 yang dimaksud dengan Pengembangan Keprofesian Berkelanjutan (PKB) adalah pengembangan kompetensi guru yang dilaksanakan sesuai dengan kebutuhan, bertahap, berkelanjutan untuk meningkatkan profesionalitasnya, khususnya bagi guru-guru yang mengabdikan diri menjadi pendidik di sekolah luar biasa (SLB). Dengan kata lain, setiap individu, termasuk guru-guru di SLB memiliki tanggung jawab untuk mengembangkan keprofesiannya sepanjang kariernya (Gray, S.L, 2005; Fitriana et.al 2018).

PKB merupakan salah satu komponen pada unsur utama yang kegiatannya diberikan angka kredit untuk kenaikan pangkat. Unsur kegiatan Pengembangan Keprofesian Berkelanjutan (PKB) terdiri dari tiga macam kegiatan, yaitu: pengembangan diri, publikasi ilmiah dan karya inovatif.

Pengembangan diri yang dimaksud diejawantahkan melalui kegiatan semacam workshop. Publikasi ilmiah meliputi membuat publikasi ilmiah atas hasil penelitian berupa jurnal dan/atau membuat publikasi buku. Karya inovatif meliputi, menemukan teknologi tetap guna, menemukan/menciptakan karya seni, membuat/memodifikasi media/alat peraga pendidikan, dan/atau mengikuti pengembangan penyusunan standar, pedoman, soal dan sejenisnya. Tujuannya dari PKB tentu agar dapat memfasilitasi guru SLB untuk terus memutakhirkan kompetensi yang menjadi tuntutan ke depan berkaitan dengan profesinya, memotivasi guru SLB agar memiliki komitmen melaksanakan tugas pokok dan fungsinya sebagai tenaga profesional; mengangkat citra, harkat, martabat profesi guru SLB, rasa hormat dan bangga kepada penyandang profesi guru.

SLB Negeri Martapura di Kabupaten Banjar, merupakan sekolah baru yang mulai operasional pada tahun 2011 dengan keadaan yang serba keterbatasan, baik sarana maupun prasarana untuk mendukung kelancaran proses belajar mengajarnya. Pada awal berdiri, tenaga pengajar sebanyak 4 (empat) orang guru yang sudah diangkat menjadi Pegawai Negeri Sipil (PNS), dan untuk mengangkat tenaga honorer juga tidak mampu, disisi lain dari tahun ke tahun jumlah murid semakin bertambah. Atas perhatian dari pemerintah Provinsi Kalimantan yang memperhatikan keadaan ini, maka diberikan tenaga pengajar yang bersifat tenaga kontrak, hal ini sangat membantu sekolah dalam mengatasi kekurangan tenaga pengajar.

Beberapa permasalahan yang ditemui di SLB Negeri Martapura, antara lain yaitu dengan tenaga pengajar yang baru tersebut, belum memiliki kompetensi yang memadai sebagai guru SLB. Sebagian besar guru belum memiliki kompetensi, dan keterampilan yang memadai sebagai pendidik dan pengajar anak berkebutuhan khusus. Sebagian besar guru belum 


\section{(A) ABDIMAS}

https://journal.uwgm.ac.id/index.php/abdimasmahakam

E-ISSN: 2549-5755

Januari 2020, Vol. 4 No. 01

memiliki kemampuan dan keterampilan dalam membuat administrasi kelas dan inovasi pembelajaran. Sebagian pendidik dan tenaga kependidikan berlatarbelakang bukan dari pendidikan luar biasa, bahkan dari lulusan SLTA/sederajat. Permasalahan tersebut muncul juga dikarenakan minimnya pelatihan atau workshop pengembangan diri dan guru professional, maupun banyak guru yang mengikuti jika ada pelatihan.

Rata-rata guru di SLB Negeri Martapura, Kalimantan Selatan, mengalami kesulitan dalam melakukan penelitian, menulis di jurnal pendidikan, serta menulis buku-buku untuk anak SLB di penerbit dan artikel ilmiah populer di media massa. Padahal, banyak masalah baik itu tentang pembelajaran maupun anak di SLB, yang bisa diangkat sebagai judul penelitian maupun artikel.

Salah satu solusi untuk menjawab masalah guru-guru SLB Negeri Martapura adalah dengan Program Kemitraan Masyarakat Stimulus (PKMS) Pengembangan Keprofesian Berkelanjutan (PKB) Bagi Guru-guru di SLB Negeri Martapura Kabupaten Banjar. Pengembangan kompetensi guru yang dilaksanakan sesuai dengan kebutuhan, bertahap, berkelanjutan untuk meningkatkan profesionalitasnya.

Tujuannya pengabdian ini adalah memberikan motivasi kepada guru-guru SLB Negeri Martapura untuk menyusun PKB dalam bentuk (1) sosialisasi selayang pandang tentang PKB (2) workshop penyusunan Penelitian Tindakan Kelas (PTK) (3) workshop menulis artikel jurnal di jurnal pendidikan (4) workshop menulis buku-buku pendidikan dan artikel ilmiah populer di media massa.

\section{Metode}

Pelaksanaan Program Kemitraan Masyarakat Stimulus (PKMS) Pengembangan Keprofesian Berkelanjutan (PKB) di SLB Negeri Martapura, dilaksanakan dari bulan April-Agustus 2019. Sasaran kegiatan PKB ini adalah guru-guru SLB Negeri Martapura yang berjumlah 28 orang. Berikut ini tabel pelaksanan kegiatan pengabdian.

\begin{tabular}{|c|c|}
\hline Hari/Tanggal & Kegiatan \\
\hline Senin, 8 April 2019 & Ijin mengadakan PKMS \\
\hline Selasa, 16 April 2019 & $\begin{array}{l}\text { Sosialisasi selayang } \\
\text { pandang tentang PKB }\end{array}$ \\
\hline Selasa, 23 April 2019 & $\begin{array}{lr}\text { Workshop } & \text { penyusunan } \\
\text { Penelitian } & \text { Tindakan } \\
\text { Kelas (PTK) } & \end{array}$ \\
\hline Selasa, 30 April 2019 & $\begin{array}{l}\text { Workshop penulisan } \\
\text { artikel di Jurnal } \\
\text { Pendidikan }\end{array}$ \\
\hline Kamis, 2 Mei 2019 & $\begin{array}{l}\text { Workshop artikel } \\
\text { ilmiah populer (opini) } \\
\text { di media massa (koran) }\end{array}$ \\
\hline Selasa, 7 Mei 2019 & $\begin{array}{l}\text { Workshop penulisan } \\
\text { buku teks }\end{array}$ \\
\hline Kamis, 9 Mei 2019 & $\begin{array}{l}\text { Pengisian lembar } \\
\text { evaluasi kegiatan }\end{array}$ \\
\hline Selasa, 6 Agustus 2019 & $\begin{array}{l}\text { Follow up kegiatan } \\
\text { PKMS }\end{array}$ \\
\hline
\end{tabular}




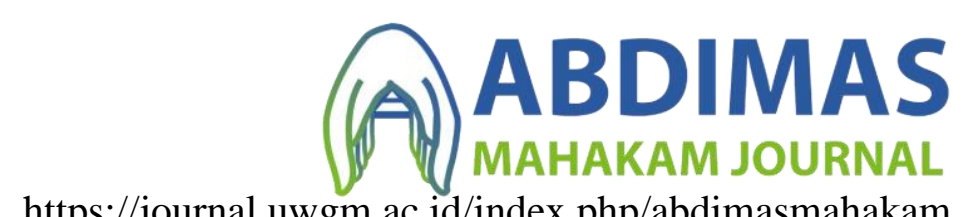

https://journal.uwgm.ac.id/index.php/abdimasmahakam

E-ISSN: 2549-5755

Januari 2020, Vol. 4 No. 01

Kegiatan PKMS PKB bagi guru-guru SLB Negeri Martapura, dilaksanakan dengan dua metode yakni sosialisasi dan workshop. Sosialisasi diperuntukan untuk kembali mengenalkan kepada guru-guru tentang apa itu Pengembangan Keprofesian Berkelanjutan (PKB), karena sebagian guru baru mendengar istilah PKB.

Sedangkan untuk workshop mencakup empat kegiatan yaitu workshop PTK, workshop penulisan jurnal pendidikan, workshop penulisan buku teks, serta workshop penulisan artikel ilmiah populer di media massa. Narasumber workshop langsung dari tim PKMS, karena melihat rekam jejak dan keahlian. Pada akhir kegiatan, dibagikan lembar evaluasi untuk mengetahui respon peserta PKMS ditinjau dari: (1) pelaksanaan yang mencakup: tema PKMS, ketepatan waktu, suasana, kelengkapan materi, sikap penyelenggara, serta (2) narasumber, yang mencakup: penguasaan materi, cara penyajian, kebermanfaatan materi, interaksi dengan peserta, dan penggunaan alat bantu.

\section{Hasil dan Pembahasan}

Kegiatan PKMS PKB bagi guru-guru di SLB Negeri Martapura dilaksanakan dalam 5 kali pertemuan (sosialisasi dan workshop) serta 1 kali pendampingan (follow up). Tim pengabdian memberikan modul sebagai panduan mengikuti kegiatan PKMS.

Deskripsi hasil pengabdian untuk masing-masing kegiatan adalah sebagai berikut.

\section{Sosialisasi Selayang Pandang tentang Pengembangan Keprofesian Berkelanjutan (PKB)}

Kegiatan sosialisasi ini dilaksanakan di awal pertemuan dengan guru-guru SLB Negeri Martapura, untuk sharing perihal PKB. Kebanyakan dari guru sudah mengerti apa itu PKB, tetapi belum sepenuhnya paham apa saja syarat yang diperlukan untuk naik pangkat.

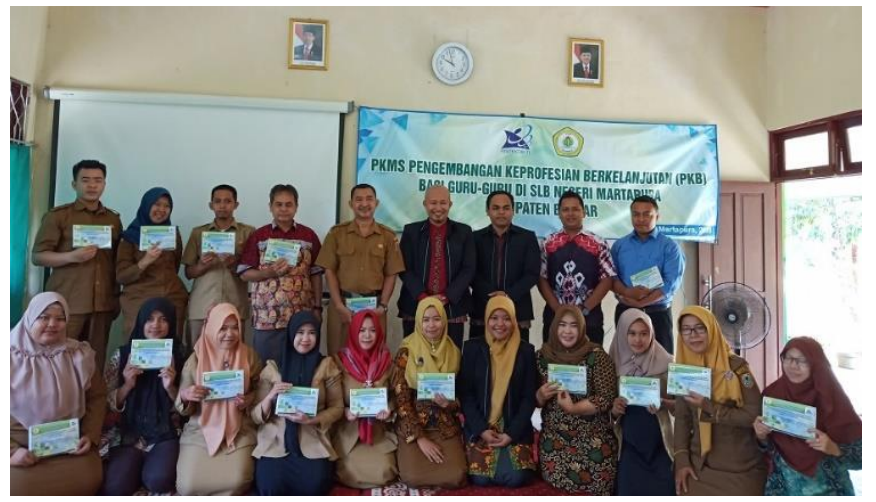

Gambar 1. Foto Bersama Guru-guru

Pemateri pada kegiatan ini menyampaikan pentingnya PKB bagi guru dan apa saja yang diperlukan untuk naik pangkat, dari golongan III/a hingga IV/e. Pada akhir kegiatan, diadakan diskusi dan tanya jawab, antara pemateri dan peserta sosialisasi, untuk mengecek kepahaman peserta akan materi yang sudah disampaikan.

\section{Workshop Penelitian Tindakan Kelas (PTK)}

Salah satu unsur wajib ada dalam pengajuan usul PKB adalah jurnal penelitian, yang diperoleh dari hasil penelitian. Di SLB Negeri Martapura banyak sekali masalah yang 


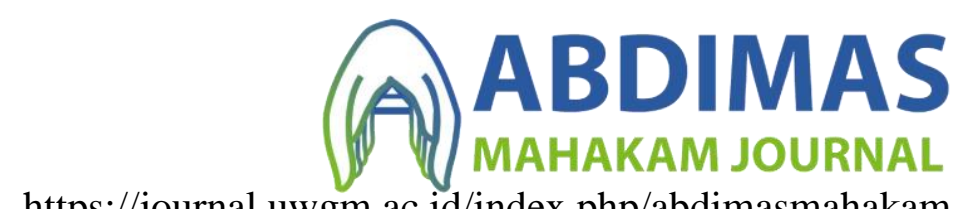

https://journal.uwgm.ac.id/index.php/abdimasmahakam

E-ISSN: 2549-5755

Januari 2020, Vol. 4 No. 01

ditemui, misalnya downsindrom yang memerlukan motivasi khusus dari guru. Salah satu jenis penelitian yang memungkinkan bagi guru-guru adalah PTK. Pemateri menyampaikan pokok-pokok yang harus ada dalam PTK seperti alur siklus yang memiliki empat kegiatan, yaitu perencanaan (planning), pengamatan (observasing), pelaksanaan (acting), serta refleksi dan evaluasi (refleksion and evaluation). Ada peserta workshop yang ingin dibimbing menyusun PTK. Kegiatan ini diakhiri dengan latihan mencari masalah dan menulis kerangka PTK yang akan dibuat.

\section{Workshop Penulisan Artikel di Jurnal Pendidikan}

Pada kegiatan workshop penulisan jurnal di jurnal pendidikan, dipandu oleh anggota tim PKMS yang memang kesehariannya bergulat sebagai pengelola jurnal pendidikan Lentera di STKIP PGRI Banjarmasin. Para peserta dipandu bagaimana cara submit di jurnal secara online. Kegiatan ini diawali dengan paparan singkat oleh tim perihal submit di jurnal pendidikan, kemudian diikuti dengan sesi tanya jawab antara narasumber dengan peserta. Kegiatan ini diakhiri dengan masing-masing peserta mencoba untuk submit dan membuat akun jurnal pendidikan.

\section{Workshop Penulisan Buku Teks}

Narasumber yang dihadirkan, kebetulan sudah menulis puluhan buku, baik itu buku teks untuk anak-anak sekolah maupun buku-buku pendidikan. Pada kegiatan ini, dikupas tuntas bagaimana cara menerbitkan buku di penerbit nasional, khususnya tentang syarat-syaratnya. Pemateri juga memberikan motivasi akan manfaat pentingnya menulis dan menerbitkan buku, yaitu selain untuk eksistensi nama, juga bisa bermanfaat untuk naik pangkat, bahkan memungkinkan untuk menjadi narasumber di berbagai pertemuan ilmiah, seperti bedah buku, penyusunan soal, dst. Kegiatan ini diakhiri dengan peserta yang menyusun draft buku untuk anak SLB.

\section{Workshop Penulisan Artikel Ilmiah Populer (Opini) di Media Massa}

Pada kegiatan ini dikupas tuntas perihal bagaimana menulis artikel ilmiah populer di koran (media massa). Dimulai dari mencari ide menulis topik-topik faktual yang disesuaikan dengan bidang keahlian para guru SLB Negeri Martapura. 
https://journal.uwgm.ac.id/index.php/abdimasmahakam

E-ISSN: 2549-5755

Januari 2020, Vol. 4 No. 01

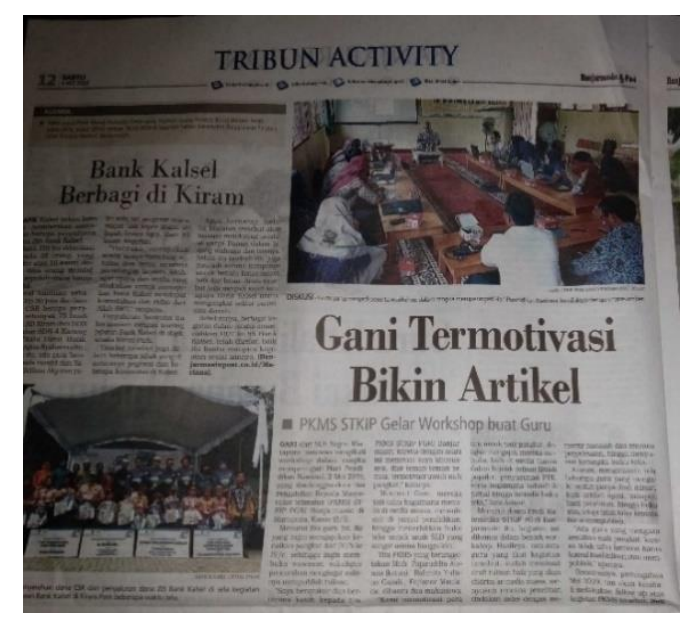

Gambar 2. Publikasi di Koran

Narasumber merupakan penulis tetap di salah satu media massa lokal Kalimantan Selatan, sehingga pada saat kegiatan, tepat tulisan publish di koran Banjarmasin Post. Di akhir kegiatan, para peserta mencari masalah yang sedang viral dan update kemudian mengaitkan dengan sumber-sumber dan data-data pendukung tulisan.

\section{Respon Peserta PKMS}

Pada akhir kegiatan, dibagikan sertfikat kepada peserta PKMS, dan dibagikan lembar evaluasi untuk mengetahui respon peserta terhadap kegiatan yang sudah dilaksanakan, tentang dua hal, yaitu pelaksanaan PKMS dan narasumber. Alternatif pilihan ada lima yaitu 1: buruk; 2: kurang; 3: cukup; 4: bagus; dan 5: memuaskan. Hasilnya, seluruh peserta yang mengisi lembar evaluasi memberikan penilaian pelaksanaan PKMS dengan nilai bagus atau memuaskan di tiap aspek yang dinilai. Tabel berikut menyajikan persentase peserta yang menilai bagus atau memuaskan.

\begin{tabular}{cll}
\hline \multirow{2}{*}{ Aspek Evaluasi } & \multicolumn{2}{c}{ Persentase } \\
\cline { 2 - 3 } & Bagus & Memuaskan \\
\hline Pelaksanaan PKMS & & \\
a. Tema PKMS & $54,5 \%$ & $45,5 \%$ \\
b. Ketepatan Waktu & $72,7 \%$ & $27,3 \%$ \\
c. Suasana & & \\
d. Kelengkapan & $63,6 \%$ & $36,4 \%$ \\
$\quad$ Materi & $45,5 \%$ & $54,5 \%$ \\
e. Sikap & $18,2 \%$ & $81,8 \%$ \\
$\quad$ Penyelenggara & & \\
Narasumber & $18,2 \%$ & $81,8 \%$ \\
a. Penguasaan & & \\
\hline
\end{tabular}


https://journal.uwgm.ac.id/index.php/abdimasmahakam

E-ISSN: 2549-5755

Januari 2020, Vol. 4 No. 01

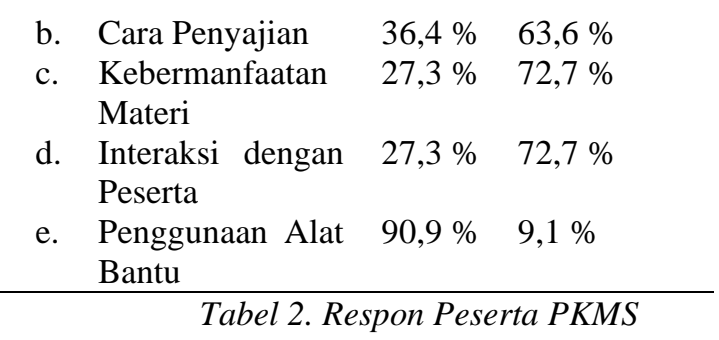

Berdasarkan tabel tersebut, nampak bahwa secara umum, para peserta PKMS menilai bagus dan merasa puas dengan kegiatan yang diselenggarakan. Pada kolom manfaat, para peserta menuliskan bahwa melalui kegiatan ini mereka jadi paham bagaimana alur melaksanakan penelitian, submit di jurnal, menerbitkan buku teks di penerbit nasional, hingga menulis opini di media massa lokal, seperti Radar Banjarmasin atau Banjarmasin Post. Mayoritas dari mereka merasa termotivasi untuk menyusun PKB, baik dari keinginan untuk melakukan penelitian tindakan kelas, menulis di jurnal pendidikan, hingga menulis artikel ilmiah populer (opini) di media massa (koran). Sedangkan di kolom saran, mayoritas peserta menginginkan adanya pendampingan agar hasil karya mereka bisa tuntas dan dapat digunakan untuk mengajukan usul pangkat.

Terakhir, kami sepakat dengan pendapat Scales, et. all, (2011), yang menyatakan bawah pengembangan keprofesian berkelanjutan bagi guru merupakan upaya untuk memelihara, meningkatkan, dan memperluas pengetahuan dan keterampilan yang relevan dengan keahlian guru, sehingga berdampak positif pada praktek dan pengalaman pembelajaran. Adanya kegiatan PKB, sedikit banyak akan memberikan nilai tambah bagi guru karena bisa meningkatkan pengetahuan, menambah semangat dalam bekerja, memotivasi kebiasaan mengajar yang lebih baik (Lessing and Witt, 2007). Serta, dapat meningkatkan pengetahuan dan keterampilan mengajarnya (Ono and Ferreira, 2010).

\section{Simpulan dan rekomendasi}

Hasil pengabdian menunjukkan bahwa guru-guru SLB Negeri Martapura lebih termotivasi untuk menyusun PKB, berupa menyusun PTK (proposal), menulis di jurnal, serta menulis buku-buku untuk anak SLB dan artikel ilmiah (opini) di media massa, meskipun baru sebatas draft. Pengabdian kepada masyarakat perlu menyentuh pada aspek pengembangan diri guru, khususnya guru-guru di SLB yang notabene waktunya dominan dicurahkan untuk mendidik anak-anak berkebutuhan khusus. Alangkah baiknya, ke depan ada program pengabdian terintegratif dengan pusat untuk memberikan workshop-workshop dan atau bimbingan teknis menyusun PKB untuk guru-guru di SLB.

\section{Ucapan Terima Kasih}

Terimakasih kepada KEMENRISTEKDIKTI yang telah mendanai penuh kegiatan Program Kemitraan Masyarakat Stimulus (PKMS) ini. 
https://journal.uwgm.ac.id/index.php/abdimasmahakam

E-ISSN: 2549-5755

Januari 2020, Vol. 4 No. 01

\section{Daftar Pustaka}

Chinien, C., \& Singh, M. (2009). Overview: Adult education for the sustainability of human kind. In International Handbook of Education for the Changing World of Work (pp.2521-2535). Dordrecht:Springer Netherlands. https://doi.org/10.1007/978-1-4020$\underline{5281-1 \_166}$

Fitriana, R., Nur, D. R., \& Arbain, A. (2017). Pelatihan dan Simulasi IELTS bagi Mahasiswa dan Dosen di Lingkungan Fakultas Pendidikan dan Keguruan Program Studi Bahasa Inggris Universitas Widya Gama Mahakam Samarinda. Jurnal Abdimas Mahakam, 1(2), 88-95.

Graal, N. (2012). Continuing professional development in the lifelong learning sector. Professional Development in Education, 38(1), 154-155. https://doi.org/10.1080/19415257.2011.574510

Gray, L., \& Leaton, S. (2005). An enquiry into continuing professional development for teachers. London: Esmee Fairbairn.

Lessing, A., \& Witt, M.de. (2007). The value of continuous professional development: Teachers' perceptions. South African Journal of Education, 27(1), 53-67. Retrieved from https://www.ajol.info/index.php/saje/article/view/25098

Lucas, B., Spencer, E., \& Claxton, G. (2012). How to teach vocational education: A theory of vocational pedagogy. (London, Ed). City \& Guilds.

Ono, Y., \& Ferreira, J. (2010). A case study of continuing teacher professional development through lesson study in South Africa. South African Journal of Education, 30(1), 59-74. Retrieved from https://www.ajol.info/index.php/saje/article/view/52602

Presiden Republik Indonesia. Undang-undang nomor 14 tahun 2005 tentang guru dan dosen. (2005). 14. Retrieved from http://www.sjdih.depkeu.go.id/full/Text/2005/15TAHUN2005UU.htm

Scales, P.,Pickering, J., \& Senior, L. (2011). Continuing professional development in the lifelong learning sector. McGraw-Hill Education (UK).

Wagner, T. (2014). The global achievement gap: Why even our best schools don't teach the new survival skills our children need-and what we can do about it. Basic Books. 